\title{
Rabbit Neoplasm
}

National Cancer Institute

\section{Source}

National Cancer Institute. Rabbit Neoplasm. NCI Thesaurus. Code C134989.

A neoplasm occurring in a rabbit. 